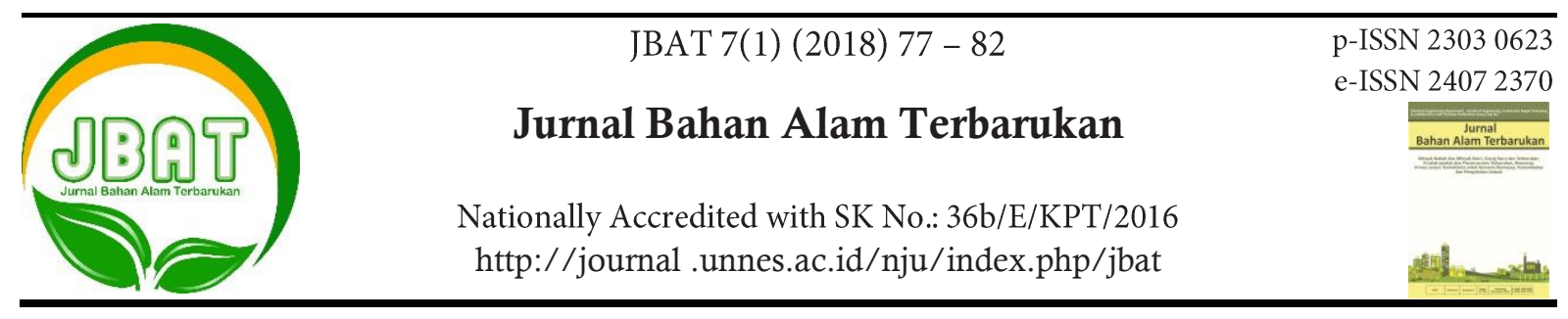

\title{
Yellow Corn Biscuits for Early Childhood: High Energy and Beta-carotene
}

\author{
Siti Fathonah ${ }^{\bowtie}$, Rosidah, Stella Septianarta
}

DOI 10.15294/jbat.v7i1.9723

Home Economic Departement, Engineering Faculty, Universitas Negeri Semarang, Semarang, Indonesia

\begin{tabular}{l} 
Article Info \\
\hline Article history: \\
Received \\
$\quad$ May 2017 \\
Accepted \\
$\quad$ October 2017 \\
Published \\
$\quad$ June 2018 \\
\hline Keywords : \\
biscuit; corn; early \\
childhood; \\
betacarotene \\
\hline
\end{tabular}

\begin{abstract}
Snacks which are most widely consumed by early childhood are biscuits. The conventional raw ingredients of biscuits are varied with yellow corn starch, which contains beta-carotene. The composition of yellow corn biscuit consists of $50 \%$ yellow corn starch, $40 \%$ wheat flour, and $10 \%$ cornstarch, and butter. The use of butter was varied in $25 \%, 30 \%$, and $35 \%$. An analysis was conducted on its energy content, protein, fat, and beta-carotene, as well as acceptance. The results of the study showed nutrient content was not entirely different from the use of margarine $25 \%$ and $35 \%$, the energy was $441-468 \mathrm{kcal}$, protein was 6.4 to $7.3 \%$, fat was 18.3 to $21.7 \%$, and beta-carotene $2,721-4,134 \mu \mathrm{g}$. The energy density of corn biscuits was $3.5-3.9 \mathrm{~g} / 1000 \mathrm{~kJ}$. Yellow corn biscuits were considered as high-energy biscuits $(>400$ $\mathrm{kcal})$. The organoleptic test of the biscuits in early childhood conducted on all indicators (color, aroma corn, fragrant aroma, and crispness, sweet and savory taste) showed that the biscuits were categorized as likable. The use of different percentage of margarine is not significant concerning the acceptability of biscuits, except for the aspect of the fragrance and sweetness between the use of margarine $30 \%$ to $35 \%$. Industrial-scale production is necessary for the dissemination of the consumption of yellow corn biscuits with margarine $35 \%$, in particular for the early childhood
\end{abstract}

\section{INTRODUCTION}

The condition of children under five in Indonesia is currently in an epidemiological situation. A total of $19.6 \%$ are malnourished, $12.1 \%$ are underweight prevalence, while the condition of high nutrition is also quite high, $11.9 \%$ (Menteri Kesehatan RI, 2013). According to the WHO, a public health problem is considered serious when the prevalence of underweight is between 10.0 to 14.0 percent and is seen as critical when the prevalence was $\geq 15,0$ percent (WHO, 2010). Therefore, Indonesia's $12,1 \%$ underweight prevalence shows that the health problem of children under five in Indonesia is categorized as serious. Consequently, this issue is urgent to overcome. Early childhood belong to the group of children under five, who are in the golden period of growth. They require high-quality food. To meet their nutritional needs, children under five require the main meal ( 3 times daily) and snack foods (2 -3 times a day).

The type of snack which is mostly consumed after milk is a biscuit (Fathonah et al., 2014). Biscuit is a food product produced by baking the dough from wheat starch with or without the use of other food ingredients and permitted food additives (Departemen Perindustrian, 1992). Varying raw ingredients of biscuits is necessary to vary the flavor and aroma are different, one of them with yellow corn flour. Excess yellow corn flour, among others, have a low glycemic index of 48 (Drummond \& Brefere, 2004), containing carotenes a high of $641 \mu \mathrm{g}$, and contains high fiber $2.2 \mathrm{~g}$ (Persatuan Ahli Gizi Indonesia, 2009). Corn has a wealth of active functional food ingredients, such as

\footnotetext{
$\triangle$ Corresponding author:

Home Economic Departement, Engineering Faculty

Universitas Negeri Semarang, Semarang, Indonesia

E-mail: fathonah@mail.unnes.ac.id
} 
fiber (dietary fiber), the composition of carbohydrates, anti-oxidants and minerals that are not owned Fe sorghum and wheat (Suarni \& Hasyim, 2011).

As observed in many previous studies, reducing the fat content or replacing fat with other ingredients has a considerable impact on the texture attributes of biscuits (Zoulias et al. 2002; RodríguezGarcía et al. 2012). Chevallier et al., (2000) concluded that biscuit structure is a composite matrix of protein aggregates, lipids, and sugars, embedding starch granules. Fat plays an important role by imparting shortness, richness, and tenderness, thereby improving the eating quality of the product. Type of fat used in the preparation of biscuits determines the quality of the end product (Jissy \& Leelavathi, 2007). This study examined the effect of the use of lipid (butter) in nutrient content and acceptance of the biscuits on Early childhood In the production of biscuits, butter serves has shortening function which makes biscuits become crispier and crumb (Lean. 2013; Gallagher et.al, 2005). The use of margarine is still lower than the $40 \%$ standard recipe (Gallagher et al., 2005).

The purpose of this study are to figure out the effect of differences in the use of margarine on energy content, protein, fat and beta-carotene in yellow corn starch biscuits, and to determine the effect of the difference in the use of margarine on the acceptance of biscuits on early childhood

\section{MATERIALS AND METHODS}

\section{The Ingredients of the Biscuits}

The composition of ingredients of the biscuits in this study is $50 \%$ yellow corn flour, $40 \%$ wheat flour and maize flour $10 \%$. The difference in the use of margarine is as follows $25 \%, 30 \%$, and $35 \%$ from the amount of flour. Other supporting ingredients are refined sugar, egg yolks, and baking powder. The composition of yellow corn biscuits ingredients is presented in Table 1.

\section{The Process of Making the Biscuits}

The process of making yellow corn flour was conducted in the following steps: the grains of yellow corn were loosened then washed, soaked for one day and then washed back and taken the husk; washed back to the net and drying it in the sun for \pm 2 days until completely dry; yellow corn milled until smooth, done up to 3 times until the texture of the flour milling process really smooth, filtered through 80 mesh size; the biscuit-making process through the following steps; margarine was mixed with powdered sugar with hand- mixer for about 3 minutes until it was well blended; add the egg yolk and mix with a hand - mixer for 2 minutes until it was well-blended; mix the yellow corn flour, wheat flour, maize flour, powdered milk and baking powder with hand-mixer for 1 minute until it was blended; roll the dough with until it was 3 millimeters thick and then cut it with a biscuit cutter; arrange the cut dough on a baking dish and put into an oven for 15 minutes at a temperature of $170^{\circ} \mathrm{C}$; then cool it for 7 minutes; and pack with hermetic packaging.

Table 1. The ingredient of Yellow Corn Biscuits

\begin{tabular}{lccc}
\hline \multirow{2}{*}{ Ingredients } & \multicolumn{3}{c}{ Margarine Usage } \\
\cline { 2 - 4 } & $\mathbf{2 5 \%}$ & $\mathbf{3 0} \%$ & $\mathbf{3 5 \%}$ \\
\hline Corn flour (g) & 250 & 250 & 250 \\
Wheat Flour (g) & 200 & 200 & 200 \\
Maize Flour (g) & 50 & 50 & 50 \\
Margarine (g) & $\mathbf{1 2 5}$ & $\mathbf{1 5 0}$ & $\mathbf{1 7 5}$ \\
Sugar Powder (g) & 200 & 200 & 200 \\
Milk Powder (g) & 25 & 25 & 25 \\
Egg yolk (g) & 170 & 170 & 170 \\
Baking powder (g) & 0.5 & 0.5 & 0.5 \\
\hline
\end{tabular}

\section{Analysis}

The energy, protein, lipid and betacarotene were determined by the method Described by the Association of Official Analytical Chemists (AOAC) 1990. Organoleptic evaluation, consumer sensory panels were selected from early childhood to evaluate the biscuits According to Reviews their likeness, using 5-points hedonic scale, in which 5 indicates like very much, and 1 indicates dislike (Setyaningsih et al.., 2010).

ANOVA analysis was conducted using SPSS software version 23 to determine the effects of the use of margarine on nutrient content and acceptability of biscuits.

\section{RESULTS AND DISCUSSION}

Yellow corn biscuits corn must have criteria for a good biscuit. The main criteria are crunchy texture. The color of the biscuit depends on starch as the primary ingredient, which is a golden yellow, but rather dull.

Snack is categorized as high-energy when the energy content is $20 \%$ or more than the Daily Value. Daily values are a set of nutrient intake 
Table 2. Nutritional Content of Yellow Corn Biscuits

\begin{tabular}{lcccc}
\hline \multirow{2}{*}{ Nutrient } & \multicolumn{3}{c}{ Margarine Usage } & SNI 01-2973 -1992 \\
\cline { 2 - 4 } & $25 \%$ & $30 \%$ & $35 \%$ & \\
\hline Energy (kcal) & $441 \pm 0.71^{\mathrm{a}}$ & $456 \pm 0.71^{\mathrm{b}}$ & $468 \pm 2.12^{\mathrm{c}}$ & Min 400 \\
Protein $(\mathrm{g})$ & $7.3 \pm 0.00^{\mathrm{a}}$ & $6.5 \pm 0.07^{\mathrm{b}}$ & $6.4 \pm 0.07^{\mathrm{b}}$ & Min 9.0 \\
Lipid $(\mathrm{g})$ & $18.2 \pm 0.14^{\mathrm{a}}$ & $20.3 \pm 0.07^{\mathrm{b}}$ & $21.7 \pm 0.14^{\mathrm{c}}$ & Min 9.5 \\
Betacarotene $(\mu \mathrm{g})$ & $2.721 \pm 19.80^{\mathrm{a}}$ & $3.278 \pm 9.90^{\mathrm{b}}$ & $4.134 \pm 9.90^{\mathrm{c}}$ & $\mathrm{Tad}$ \\
Energy density $(\mathrm{g} / 1000 \mathrm{~kJ})$ & $4.00 \pm 0.00^{\mathrm{a}}$ & $3.45 \pm 0.07^{\mathrm{b}}$ & $3.30 \pm 0.00^{\mathrm{b}}$ & $\mathrm{Tad}$ \\
\hline
\end{tabular}

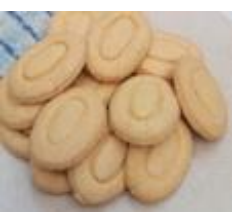

(a)

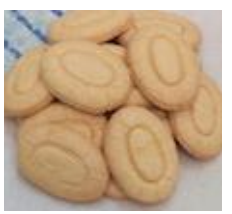

(b)

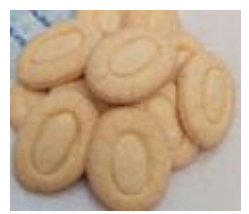

(c)
Figure 1. Yellow corn biscuits with the variation on the use of margarine (a) $25 \%$, (b) $30 \%$, dan c) $35 \%$.

value that is used as a reference for expressing nutrient content on nutrition labels. The daily value for certain nutrients at both the 2,000-calorie and 2500-calorie levels (Drummond \& Brefere, 2004). When referring to 2,000 $\mathrm{kcal}$, biscuits can be considered as high - energy if it contains $400 \mathrm{kcal}$. According to the table- 2 is known energy content of yellow corn biscuits between 441-468 kcal. Therefore, it can be categorized as high-energy. High energy biscuits are also produced by using green peanuts with energy content of $402-453 \mathrm{kcal}$ (Fathonah \& Muvida, 2015) and purple sweet patato with energy content of 490 - $515 \mathrm{kcal}$ (Fathonah \& Sari, 2015). The high energy content suits the need for children under five requiring highly nutritious foods, including energy.

The expanded list of serving size for the food guide pyramid states that four small cookies (Drummond \& Brefere, 2004). The cookies had a weight of $5 \mathrm{~g}$, and one serving size means $20 \mathrm{~g}$. One serving size contains the energy as much as $20 / 100$ $\mathrm{x} 441 \mathrm{kcal}=88 \mathrm{kcal}$.

Similarly, other nutrients have met ISO standards, except for protein content which has not fulfilled ISO standards. The protein content of these biscuits was lower when compared with the nutrient content of $80 \%$ peeled corn biscuits with the addition of $10 \%$ sugar whose protein content is $12.92 \%$, crude fiber content is $3.2 \%$, and the content of beta-carotene is 1,739 ppm (Arisanto, 2014).

Based on ANOVA test, the use of margarine provided significant differences in energy content, protein, fat and beta-carotene, except for protein content. The use of 25\% margarine and 30\% margarine did not have a significant effect on the protein content because the margarine contains 720 $\mathrm{kcal} / 100 \mathrm{~g}$, fat $81.6 \mathrm{~g} / 100 \mathrm{~g}$ and retinol $606 \mathrm{ug} /$ $100 \mathrm{~g}$. Meanwhile, the protein content which is 0.6 $\mathrm{g} / 100 \mathrm{~g}$ is categorized as quite small (Persatuan Ahli Gizi Indonesia, 2009)

The total fat of this yellow corn biscuit was $18.2-21.7 \%$ which is still within reasonable limits when compared biscuits in the market. The results of the study of 12 kinds of biscuits in Pakistan showed that a fat content varied from 13.7 to $27.6 \%$ (Kandhro, 2008). The results of analysis of 46 samples biscuit sold in Indian market showed that the total fat content ranged from 9.5 to $25.0 \mathrm{~g} / 100$ $\mathrm{g}$ of biscuits (Kala. 2014). The total fat contents of the six types of biscuit samples produced by four different Turkish manufacture ranged between $8.5 \%$ and $26.0 \%$ (Daglioglu et al., 2000). High-fat content is very good when consumed by children under five who still requires a high fat content to support their growth and immunity. It is important to note that biscuits containing high-fat content have more limited storage span. Filipčev et al., (2014) confirms that higher fat content has an effect in maintaining the flavor during storage.

The content of beta-carotene is quite high on corn biscuits which are between 2721-4134 $\mu \mathrm{g} .1$ $\mu \mathrm{g}$ retinol $=6 \mu \mathrm{g}$ beta-carotene (Almatsier, 2003). When converted to retinol, the beta - carotene content is equal to 453.5 - $689 \mu \mathrm{g}$ retinol. The needs for vitamin A for children under five is $400 \mu \mathrm{g}$ retinol (Menteri Kesehatan RI, 2013). The consumption of $100 \mathrm{~g}$ of this yellow corn biscuits was able to meet the needs of vitamin A per day. It shows that yellow corn biscuits can be considered as a functional food as a source of vitamin A. Betacarotene is one of the carotenoids which possesses antioxidant functions. Beta-carotene helps to protect the nutrients which are easily oxidized, such as PUFAs from oxidation and can 
Table 3. The Results of Organoleptic Test of Yellow Corn Biscuits

\begin{tabular}{lccc}
\hline \multirow{2}{*}{ Sensory Aspects } & \multicolumn{3}{c}{ Margarine Usage } \\
\cline { 2 - 4 } & $25 \%$ & $30 \%$ & $35 \%$ \\
\hline Color & $3.68 \pm 1.29^{\mathrm{a}}$ & $3.66 \pm 0.99^{\mathrm{a}}$ & $3.78 \pm 1.12^{\mathrm{a}}$ \\
Corn Flavour & $3.78 \pm 1.15^{\mathrm{a}}$ & $3.60 \pm 1.12^{\mathrm{a}}$ & $3.69 \pm 1.19^{\mathrm{a}}$ \\
Fragrant Flavour & $3.68 \pm 1.06^{\mathrm{a}}$ & $3.81 \pm 0,94^{\mathrm{a}}$ & $4.13 \pm 0.93^{\mathrm{b}}$ \\
Crispness & $3.66 \pm 1.20^{\mathrm{a}}$ & $3.73 \pm 1.00^{\mathrm{a}}$ & $3.99 \pm 1.02^{\mathrm{a}}$ \\
Sweetness & $3.50 \pm 1.31^{\mathrm{a}}$ & $3.86 \pm 1.00^{\mathrm{a}}$ & $3.95 \pm 1.16^{\mathrm{b}}$ \\
Tastiness & $3.75 \pm 1.19^{\mathrm{a}}$ & $3.88 \pm 1.02^{\mathrm{a}}$ & $4.05 \pm 0.87^{\mathrm{a}}$ \\
Overall & $3.67 \pm 0.78^{\mathrm{a}}$ & $3.77 \pm 0.49^{\mathrm{a}}$ & $3.91 \pm 0.53^{\mathrm{b}}$ \\
Criteria & Like & Like & Like \\
\hline
\end{tabular}

resist the harmful effects of free radicals in the body (Lean, 2013).

The very high content of beta-carotene is required to support vitamin A deficiency which still occurs in children under five in Indonesia. Research in 2013 showed that the figure of corneal opacities prevalence nationally was $5.5 \%$ with the highest prevalence found in Bali (11.0\%), followed by DI Yogyakarta (10.2\%) and South Sulawesi (9.4\%). The prevalence of corneal opacities in children under five years of $0.8 \%$ (Menteri Kesehatan RI, 2013).

The energy density is high enough yellow corn biscuits between 3.5 - 3.9. The energy density is getting smaller with a higher fat usage. The high energy density is very good to be consumed by children under five " have a limited digestive capacity (More, 2014). A small portion of yellow corn biscuit consumption has been able to meet their nutritional needs of Early childhood.

The results of the organoleptic test of the yellow corn biscuits in children under five showed that the use margarine on the biscuits with $50 \%$ yellow corn had better acceptance rate, except in the aspect of maize scent (Table 3). It shows that margarine had positive effects to enhance the organoleptic qualities of the biscuits. Margarine has a plastic trait so that it can be easily mixed with biscuit dough and inflate well when mixed resulting in a crunchy texture. Fat makes food more delicious (Ferreira et al., 2015). The overall consumer acceptance was significantly higher $(p<0.05)$ in the shortening (oil-water-emulsion cellulose ether) biscuits. However, their scores were very similar to those of the cellulose (maximum difference $1.1 / 9$ points).

The results of the study biscuits which are composed of $100 \%$ cassava starch were more acceptable and favorable compared to the wheat biscuits (Akingbala et al., 2011). The use of SF flour with the $50 \%$ composition resulted in high quality.
Meanwhile, the $5-10 \%$ substitution of Reb Ibi Ngaoundre (RIB) were either acceptable as or better than $100 \%$ wheat biscuit (Himeda et al., 2014).

Peeled corn starch (yellowish white) and wheat starch (white) do not have an impact on the color of the biscuit which is brownish yellow / gold. The color is the result of sugar reaction which causes non-enzymatic browning. During the baking process, sugar has an effect on flavor, dimensions, color, hardness, and surface of the biscuits (Gallagher et al., 2005). More vivid biscuit surface color with yellow tone Increased probably due to a formation of products of Maillard reactions (Kulp et al., 1991; Filipčev et al., 2014).

The reaction between sugars and fats which cause the scent is evident in the use of $25 \%$ and $30 \%$ fat. It is different with the biscuit with $35 \%$ margarine. The use of $35 \%$ margarine provides more fragrant aroma which eraly childhood like.

The use of margarine does not have a significant impact on the acceptability aspects of its crispy texture and a savory taste in yellow corn biscuit. However, the mean value of the acceptability is better with the use of more margarine. It occurs because the function of margarine as a shortening fat which increases the crunchy texture of biscuits (Lean, 2013). The use of margarine produces biscuit with crispier texture because the function of margarine is to soften the texture of biscuits and it makes biscuit crumbs with high quality (Gallagher et al., 2005; O'Brien et al., 2003). Margarine serves as a shortener. The fat covers the starch and gluten from the flour with a thin layer of grease. Therefore, it breaks the structure and prevents the formation of hard mass. It causes the biscuits had soft and short crumbs. The greater the proportion of fat in the mixture, the greater the shortening effect (Ferreira et al., 2015). In accordance with the study on the use of $50 \%$ peanut butter, the overall sensory quality of experimental biscuits is improved when 50\% 
vanaspati (hydrogenated fat) is replaced by peanut butter in the standard biscuits recipe. The biscuits are prepared with $50 \%$ supplementation of peanut butter had a greater acceptability by sensory evaluation panel (Gajera et al., 2010). Biscuits with composite flour (cereals, legumes, millets, soy protein isolate, a dairy ingredient and fruit without refined flour) with sprouted flour had higher acceptability and were more superior to refinedflour biscuits (Murugkar, 2015). Another study using plantain and chickpea starch up to $20 \%$ provide sensory quality similar to a biscuit with $100 \%$ raw ingredients of flour (Yadav et al., 2012). Biscuits enriched with sorghum (30-50\%) have the higher quality of sensory, softness and crispiness compared with controls $(100 \%$ wheat starch) but lower than the biscuits substitution with rye starch (black wheat flour) (30-50\% ) (Filipcev et al., 2011).

\section{CONCLUSION}

Corn biscuits in the high energy category of $441-468 \mathrm{kcal}$, protein was 6.4 to $7.3 \%$, fat was 18.3 to $21.7 \%$. The content of betacarotene $2,721-4,134$ $\mu \mathrm{g}$. Early child acceptance on all category indicators are likable. Corn biscuits are good for early childhood consumption in support of growth

\section{ACKNOWLEDGMENT}

Thank you for DP2M research competitive grants scheme for providing research funding.

\section{REFERENCES}

Akingbala, J. O., Falade, K. O. and Ogunjobi, M. A. 2011. The Effect of Root Maturity, Preprocess Holding and Flour Storage on the Quality of Cassava Biscuit. Food and Bioprocess Technology. 4(3):451-457

Almatsier, S. 2003. Prinsip Dasar Ilmu Gizi. Gramedia Pustaka Utama. Jakarta.

AOAC, 1990. Association of Official Analysis Chemists. Official methods of analysis (15th Ed.). Virginian. Association Official Analytical Chemists. USA.

Arisanto. 2014. Pengaruh Jumlah Gula Yang Berbeda Terhadap Kualitas Inderawi Biskuit Jagung Lepas Kulit Dan Biskuit Jagung Berkulit. Skripsi. Jurusan Teknologi Jasa dan Produksi. Fakultas Teknik, Universitas Negeri Semarang.
Chevallier, S., Colonna, P., Buleon, A., Della, V. G. 2000. Journal of Agricultural, Food and Chemistry. 48:1322-1326.

Daglioglu, O., Tasan, M., Tuncel, B. 2000. Determination of fatty acid composition and total trans fatty acids of Turkish biscuits by capillary gas-liquid chromatography. European Food Research and Technology. 211(1): 41-44

Departemen Perindustrian RI. 1992. SNI 01-29731992. Departemen Perindustrian RI.

Drummond, K. E., Brefere, L. M. 2004. Nutrition for Foodservice \& Culinary Professionals. USA : John Wiley \&Sons, Inc.

Fathonah, S., Muvida, F. A. 2015. Mung bean biscuits for early childhood. Proceeding of $1^{\text {st }}$ Unnes International Conference on Research Innovation \& Commercialization for the Better Life 2015. ISSN: 2460-5832.

Fathonah, S., Sari, D.F. 2015. Purple Sweet Potato Biscuits with Different Margarine Usage. Proceeding of International Conference on Green Technology. ISSN:2355-3456

Fathonah, S., Rosidah, Sarwi. 2014. "Nutritional Adequacy Level of Snack toward Nutritional Status of Early Childhood". Greener Journl of Epidemiology and Public Health. 2(2): 037-044

Ferreira, M. S. L., Santos, M. C. P., Moro, T. M. A. Basto, G. J., Andrade, R. M. S., Gonçalves, É. C. B. A. 2015. Formulation and characterization of functional foods based on fruit and vegetable residue flour. Journal of Food Science and Technology. 52(2): 822-830.

Filipcev, B , Simurina, O., Sakac, M., Sedej, I., Jovanov, P., Pestoriće, M., BodrozaSolarov, M. 2011. Feasibility of use of buckwheat flour as an ingredient in ginger nut biscuit formulation. Food Chemistry. 125(1): 164-17

Filipcev, B., Simurina, O., Bodroza-Solarov, M. 2014. Quality of gingernut type biscuits as affected by varying fat content and partial replacement of honey with molasses. Food Science and Technology. 51(11): 31633171.

Gajera, H.P., Kapopara, M. B., Patel, V. H. 2010. Application of peanut butter to improve fatty acid composition of biscuits. Journal 
of Food Science and Technology. 47(3): 285-289.

Gallagher, E., O’ Brien, C. M., Scannell, A. G. M., Arendt, E. K. 2005. Evaluation of sugar replacers in short dough biscuit production. Journal of Food Engineering, 56, 261-263.

Himeda, M., Yanou, N. N., Fombang, E. Facho, E., Kitissou, P., Mbofung, C. M. F., Scher, J. 2014. Chemical composition, functional and sensory characteristics of wheat-taro composite flours and biscuits. Journal of Food Science and Technology. 51(9): 1893-1901.

Jissy, J., Leelavathi, K., 2007. Effect of fat type on cookie dough andcookie quality. Journal of Food Engineering. 79:299-305.

Kala, A. L. A., 2014. Studies on saturated and trans fatty acids composition of few commercial brands of biscuits sold in Indian market. Journal of Food Science and Technology. 51(11): 3520-3526.

Kandhro, A., Sherazi, S. T. H., Mahesar, S. A., Bhanger, M. I., Talpur, M. Y., Arain, S. 2008. Monitoring of Fat Content, Free Fatty Acid and Fatty Acid Profile Includingtrans Fat in Pakistani Biscuits. Journal of the American Oil Chemists' Society. 85(11): 1057-1061.

Kulp, K., Lorenz, K., Stone, M. 1991. Functionality of carbohydrate ingredients in bakery products. Food Technology, 45(3): 136-140.

Lean, M. E. 2013. Ilmu Pangan, Gizi dan Kesehatan. Terjemahan. Yogyakarta: Pustaka Pelajar.

Menteri Kesehatan, RI. 2013a. Riset Kesehatan Dasar. Departemen Kesehatan, Republik Indonesia.

Menteri Kesehatan RI. 2013b. Peraturan Menteri Kesehatan Republik Indonesia Nomor 75 Tahun 2013, Tentang Angka Kecukupan Gizi Yang Dianjurkan Bagi Bangsa Indonesia. Departemen Kesehatan .

More, J. 2014. The Nutrition on Toddlers, Children, and Teenagers.. Translated. Yogyakarta: Pustaka pelajar.
Murugkar, D. A., Gulati, P., Kotwaliwale, N., Gupta, C. 2015. Evaluation of nutritional, textural and particle size characteristics of dough and biscuits made from composite flours containing sprouted and malted ingredients. Journal of Food Science and Technology. 52(8): 5129-5137.

Schober, T. J., O'Brien, C. M., McCarthy, D., Darnedde, A., Arendt, E. K. 2003. Influence Of Gluten Free Flour Mixes And Fat Powders On The Quality Gluten free Biscuit. Journal National Food and Nutritional Sciences. 369-376. Irlandia

Okafor, J.N.C., G.I. Okafor , K. Leelavathi , S. Bhagya and G.N. Elemo, 2015. Effect of Roasted Bambara Groundnut (Voandzeia subterranea) Fortification on Quality and Acceptability of Biscuits. Pakistan Journal of Nutrition. 14 (10): 653-657.

Persatuan Ahli Gizi Indonesia, 2009. Tabel Komposisi Bahan Pangan. Kompas Gramedia, Indonesia.

Rodríguez-García, J., Laguna, L., Puig, A., Salvador, A., Hernando, I. 2012. Effect of fat replacement by inulin on textural andstructural properties of short dough biscuits. Food and Bioprocess Technology. 6(10): 2739-2750.

Setyaningsih, D., Apriyantono, A., Sari, M. P. 2010. Sensory Analysis for Food Industries and Agro. Bogor: IPB Press,.

Suarni, Yasin, M. 2011. Jagung sebagai Pangan Fungsional. Iptek Tanaman Pangan. 6(1): 41-56.

World Health Organization. 2010. The World Health report 2010: Health Systems Financing The Path To Universal Coverage.WHO, Geneva.

Yadav, R. B., Yadav, B. S. Dhull, N. 2012. Effect of incorporation of plantain and chickpea flours on the quality characteristics of biscuits. Journal of Food Science and Technology. 49(2): 207-213.

Zoulias, E. I., Oreopoulou, V., Tzia, C. 2002. Textural properties oflow-fat cookies containing carbohydrate- or protein-based fat replacers. Journal of Food Engineering. 55(4): 337-342. 